\title{
CONCENTRATIONS OF OESTROGENS AND PROGESTERONE IN THE PLASMA OF OVARIECTOMIZED AND OVARIECTOMIZED NORGESTREL-TREATED PREGNANT GUINEA-PIGS
}

\author{
DOREEN V. ILLINGWORTH AND J. R. G. CHALLIS \\ Agricultural Research Council, Institute of Animal Physiology, \\ Babraham, Cambridge
}

(Received 10th Fuly 1972)

\begin{abstract}
Summary. Ovariectomy and/or adrenalectomy of guinea-pigs did not significantly affect the plasma concentration of total unconjugated oestrogens throughout pregnancy when compared to intact animals. This indicates that oestrogen production in the pregnant guinea-pig is predominantly extra-ovarian. The plasma concentrations of progesterone in animals ovariectomized between Day 3 and Day 5 post coitum (p.c.) and treated with Norgestrel to maintain pregnancy increased appreciably only after Day 30 p.c., and rose to levels not significantly different from those in animals ovariectomized later in pregnancy or in intact controls. This confirms the findings of other workers that the secretion of progesterone by extra-ovarian sites (the placentae) is important only during the second half of gestation. In Norgestrel-treated animals, masculinization of the maternal external genitalia was not seen during pregnancy but developed within 5 days after parturition.
\end{abstract}

\section{INTRODUCTION}

We have recently reported the concentrations of progesterone and total unconjugated oestrogens in the arterial plasma of guinea-pigs throughout the course of pregnancy (Challis, Heap \& Illingworth, 1971). The plasma progesterone concentration rose steeply between Days 15 and 30 of pregnancy, and the high levels $(>200 \mathrm{ng} / \mathrm{ml}$ ) were maintained during the rest of gestation. Total unconjugated oestrogens, measured by radioimmunoassay, were undetectable before Day 25 of pregnancy, and rose only gradually to maximum values of 50 to $60 \mathrm{pg} / \mathrm{ml}$ between Days 55 to 60 post coitum (p.c.). There was a slight decrease in the plasma concentration of unconjugated oestrogens before parturition.

Ovariectomy during the second half of gestation does not usually interrupt pregnancy in the guinea-pig (Herrick, 1928; Courrier, Kehl \& Raynaud, 1929; Artunkal \& Colonge, 1949). In ovariectomized animals, plasma progesterone levels were highest at the end of gestation and were closely correlated with 
increasing placental weight, thereby indicating an increased placental secretion of the steroid (Heap \& Deanesly, 1966).

The synthetic progestagen, Norgestrel, will maintain pregnancy in ovariectomized animals during the period of ovarian dependence (Illingworth \& Deanesly, 1972). Since Norgestrel does not cross-react in the assays used for progesterone and total unconjugated oestrogens, natural steroid hormones can be measured throughout pregnancy in animals ovariectomized soon after mating.

In the present study, the levels of both oestrogen and progesterone in animals ovariectomized after Day 40 p.c. and in animals ovariectomized and treated with Norgestrel early in pregnancy have been followed. In a further group of animals, maternal adrenalectomy was performed during late pregnancy in order to establish the contribution of this gland to peripheral steroid levels. In this way, it has been possible to investigate the extra-ovarian production of steroid hormones by the pregnant guinea-pig.

\section{MATERIALS AND METHODS}

\section{Animals}

The guinea-pigs were derived from the Institute's colony of MRC-strain albino animals. Day 0 of pregnancy was determined as the morning on which a vaginal plug was found or, in the case of post-partum mated animals, the day of parturition.

\section{Operative procedures}

Ovariectomy was performed by double flank incisions under ether anaesthesia after preliminary Avertin sedation. Avertin (a solution of tribromoethanol, Bayer Products Ltd) prevents the squirming movements seen when only ether is used. The solution $(0.5 \mathrm{ml}$ Avertin, $2 \mathrm{ml}$ ethanol and $25 \mathrm{ml}$ sterile $0.9 \%$ saline) was administered intraperitoneally at a dose of $1 \mathrm{ml} / 100 \mathrm{~g}$ body wt. Five guinea-pigs were ovariectomized between Day 3 and Day 5 p.c. and three to four tablets of Norgestrel (DL-17 $\alpha$-ethynyl-17-hydroxy-18-methyl-4androsten-3-one, John Wyeth \& Brother Ltd), totalling 80 to $90 \mathrm{mg}$, were implanted subcutaneously at the time of ovariectomy (Group 1). Five guinea-pigs were ovariectomized between Day 40 and Day 45 of pregnancy (Group 2).

Complete adrenalectomy of the guinea-pig is difficult to perform, particularly since the right adrenal is closely associated with the vena cava (see Clayton \& Prunty, 1953). Anaesthesia was induced with Avertin and maintained by ether. The adrenal glands were exposed by double flank incisions, ligated and excised; adrenal remnants were destroyed by cautery. After recovery from the operation, the animals were given daily injections of cortisone acetate $(12.5 \mathrm{mg} / \mathrm{day}$, Cortistab, Boots Ltd). Abortions and/or death frequently followed this operation, and gestation continued in only two out of ten animals after total adrenalectomy in mid-pregnancy. A further one out of three animals survived adrenalectomy without abortion after ovariectomy had been performed 2 weeks earlier. Although the two adrenalectomized animals aborted (probably due to the stress of repeated anaesthesia and blood sampling), the adrenalecto- 
mized/ovariectomized guinea-pig gave birth to live young at the normal time. Brooks, Clayton \& Hammond (1960) report the birth of live young to adrenalectomized guinea-pigs. Microscopical sections through the scar tissue, removed at autopsy, showed no residual glandular tissue in these three animals which comprised Group 3.

\section{Sampling}

Serial blood samples (approximately $2 \mathrm{ml}$ ) were taken by cardiac puncture from animals lightly anaesthetized with ether or Nembutal $(40 \mathrm{mg} / \mathrm{kg}$ body wt). The samples were transferred into heparinized tubes, centrifuged, and the plasma was stored at $-15^{\circ} \mathrm{C}$ until analysis. Ovariectomized Norgestrel-treated animals were bled at approximately weekly intervals. Samples were taken approximately every 5 days from the animals ovariectomized late in pregnancy.

\section{Steroid assays}

Progesterone and total unconjugated oestrogens were assayed on the same day, eliminating repeated freezing and thawing of the samples. Progesterone was measured by a competitive protein-binding method (Thorburn, Bassett \& Smith, 1969; Challis et al., 1971) and oestrogens by radioimmunoassay as previously described (Challis et al., 1971). Norgestrel does not interfere with the competitive protein-binding assay for progesterone since it has little affinity for corticosteroid-binding globulin $(<1 \%$ cross-reaction; Illingworth \& Deanesly, 1972).

\section{Metabolic clearance rate $(M C R)$}

Two guinea-pigs were ovariectomized, one on Day 39 and the other on Day 40 of pregnancy. The metabolic clearance rate of progesterone was measured by a continuous isotope-infusion method (Illingworth, Heap \& Perry, 1970) 4 and 3 days later, respectively.

\section{RESULTS}

\section{Group 1. Ovariectomized early in pregnancy, Norgestrel-treated}

Absorption from the Norgestrel tablets over the 70- to 80-day experimental period was 0.15 to $0.22 \mathrm{mg} /$ day. Although lower doses of Norgestrel can maintain pregnancy (Illingworth \& Deanesly, 1972), the doses used in these experiments ensured that sufficient progestagen was absorbed.

Progesterone (Text-fig. 1a) was undetectable in plasma before Day 15 of pregnancy, but the concentration rose to $100 \pm 25.6 \mathrm{ng} / \mathrm{ml}$ (mean \pm S.E., $n=7)$ by Days 31 to 40 , reaching the highest levels of $308 \pm 45 \mathrm{ng} / \mathrm{ml}(n=3)$ between Day 61 and parturition. After delivery, the levels fell rapidly and were undetectable 3 days after parturition. Whereas the pattern of plasma progesterone levels differed considerably from that observed in the intact animal (histogram, Text-fig. 1a), the pattern of total unconjugated oestrogens in plasma was similar to that of intact animals (Text-fig. 1b). In one guinea-pig, the concentration of total unconjugated oestrogens was at the bottom end of the normal range (the maximum value in this animal was $6 \mathrm{pg} / \mathrm{ml}$ ), and this accounts for the large standard error of the mean value in this group. 

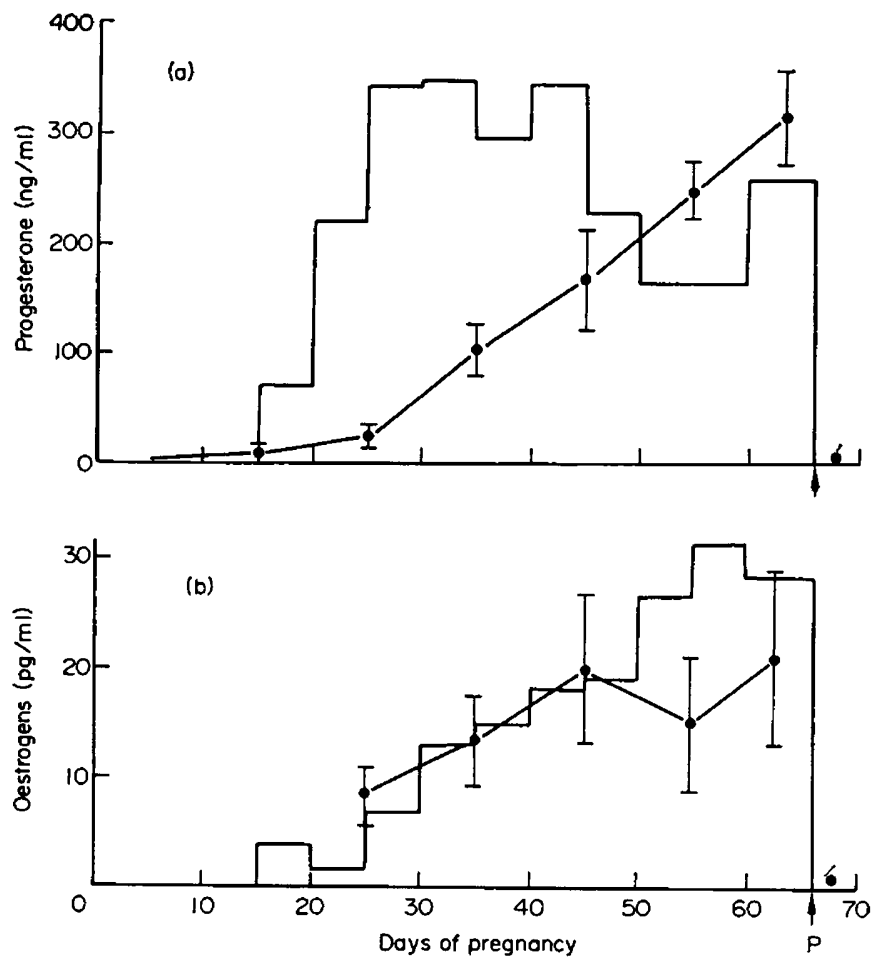

TEXT-FIG. 1. The concentrations of (a) progesterone and (b) total unconjugated oestrogens in the arterial plasma of pregnant guinea-pigs, ovariectomized between Day 3 and Day 5 p.c., and maintained with Norgestrel. All values, mean \pm S.E.M.; $n=3$ to 7 . The length of pregnancy has been back-dated from the day of parturition (Day 66), indicated by the arrow. The histogram shows the mean values for intact pregnant guinea-pigs found by Challis et al. (1971).

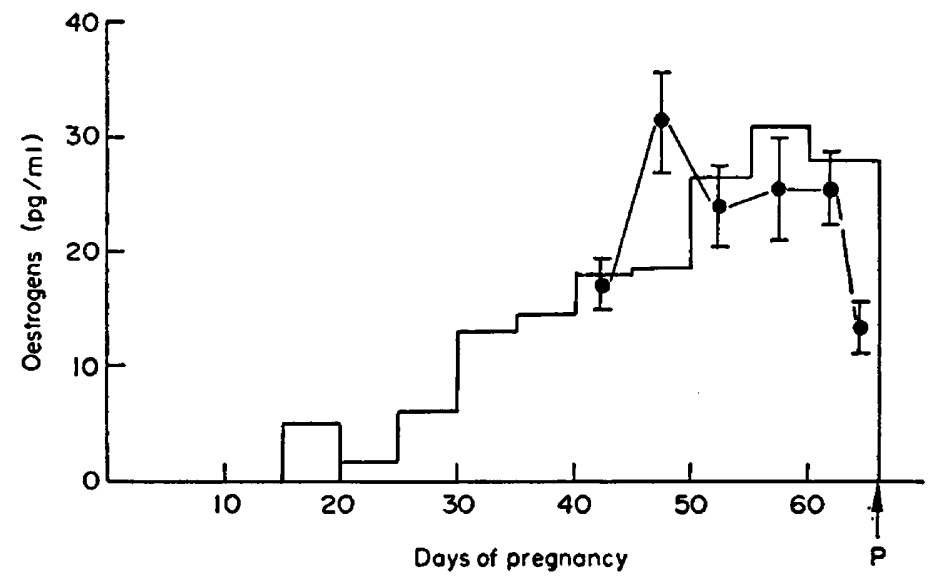

TEXT-FIG. 2. The concentrations of total unconjugated oestrogens in the plasma of five pregnant guinea-pigs, ovariectomized between Day 40 and Day 45 p.c. The first sample was taken immediately before ovariectomy. The length of pregnancy has been back-dated from the day of parturition (Day 66), indicated by the arrow. The histogram shows the mean values for intact pregnant guinea-pigs found by Challis et al. (1971). 
The mean arterial progesterone concentration in the plasma of ovariectomized Norgestrel-treated guinea-pigs has been compared to the placental weight figures given by Heap \& Deanesly (1966). There was a significant correlation between systemic progesterone concentrations and placental weight $(r=0.985$, $P<0 \cdot 01$ ), and the equation for the regression was y $=33 \cdot 76+39 \cdot 60 \mathrm{x}$.

\section{Group 2. Ovariectomy after Day 40 p.c., no synthetic progestagen}

When the animals were ovariectomized late in pregnancy, plasma progesterone levels fell precipitously, from $273 \pm 60 \mathrm{ng} / \mathrm{ml}(n=5)$ to $124 \pm 9 \mathrm{ng} / \mathrm{ml}$, 4 to 5 days later. The concentration of progesterone in plasma then rose during the remainder of gestation, reaching $210 \pm 38 \mathrm{ng} / \mathrm{ml}$ at parturition. This result is similar to that reported by Heap \& Deanesly (1966). In two out of five animals, the progesterone levels on Day 64 or 65 were lower than on Days 59 to 63 , although this is probably a reflection of the wide variation seen within individual animals. Plasma oestrogens showed no post-operative fall, but continued to rise as in intact guinea-pigs (Text-fig. 2). For all five animals, the mean concentration between Days 64 and parturition $(12 \cdot 7 \pm 2 \cdot 7 \mathrm{pg} / \mathrm{ml}, n=5)$ was significantly lower than the mean maximum value seen between Days 55 and 59 $(25 \cdot 3 \pm 4 \cdot 1, n=9, P<0 \cdot 05)$. A similar fall before parturition has been seen in some, though not all, intact animals (Challis et al., 1971).

Table 1. Production rate of progesterone after ovariectomy of pregnant guinea-pigs

\begin{tabular}{|c|c|c|c|c|}
\hline Animal & Time & $\begin{array}{c}M C R \\
(\mathrm{ml} / \mathrm{min})\end{array}$ & $\begin{array}{c}\text { Plasma progesterone } \\
(\mathrm{ng} / \mathrm{ml})\end{array}$ & $\begin{array}{c}\text { Production rate } \\
(M C R \times \text { plasma level }) \\
(\mu g / \text { min })\end{array}$ \\
\hline 1 & $\begin{array}{l}\text { Pre-ovariectomy, Day } 40 \\
3 \text { Days post-ovariectomy, } \\
\text { Day } 43\end{array}$ & $\begin{array}{l}5 \cdot 0^{*} \\
5 \cdot 89\end{array}$ & $\begin{array}{r}263 \\
50\end{array}$ & $\begin{array}{l}1 \cdot 31 \\
0.35\end{array}$ \\
\hline 2 & $\begin{array}{l}\text { Pre-ovariectomy, Day } 39 \\
4 \text { Days post-ovariectomy, } \\
\text { Day } 43\end{array}$ & $\begin{array}{l}5 \cdot 0^{*} \\
5 \cdot 74\end{array}$ & $\begin{array}{l}238 \\
121\end{array}$ & $\begin{array}{l}1 \cdot 19 \\
0 \cdot 69\end{array}$ \\
\hline
\end{tabular}

* Value for the MGR (metabolic clearance rate) at the time of the pre-ovariectomy sample calculated from previous data (D.V. Illingworth, unpublished data).

\section{Group 3. Adrenalectomized animals}

Four $2 \cdot 5-\mathrm{ml}$ blood samples were obtained by heart puncture from two bilaterally adrenalectomized animals. The mean progesterone concentration during the 2 weeks after the operation was $340 \pm 58 \mathrm{ng} / \mathrm{ml}$ and the mean total unconjugated oestrogen concentration was $42 \cdot 7 \pm 3 \cdot 5 \mathrm{pg} / \mathrm{ml}$. The mean steroid levels in three samples taken on Days 58, 62 and 64 from the third animal, after ovariectomy on Day 40 and adrenalectomy on Day 55, were $236 \pm 120$ $\mathrm{ng} / \mathrm{ml}$ and $32.6 \pm 8.9 \mathrm{pg} / \mathrm{ml}$ (progesterone and oestrogens, respectively). The steroid levels were not significantly different from those in intact animals.

When the concentrations of progesterone and total unconjugated oestrogens in the two groups of ovariectomized animals during the last week of pregnancy were compared with those in intact animals (see Challis et al., 1971), no significant difference was found for either steroid between any two experimental 
groups. Nevertheless, the mean progesterone concentration between Day 64 and parturition in the ovariectomized Norgestrel-treated animals $(308 \pm 45$ $\mathrm{ng} / \mathrm{ml}, n=3)$ was higher than in animals ovariectomized after Day $40(210 \pm 38$ $\mathrm{ng} / \mathrm{ml}, n=5)$ and in intact guinea-pigs (258 $\pm 22 \mathrm{ng} / \mathrm{ml}, n=15)$.

\section{Progesterone production rates in ovariectomized guinea-pigs}

After ovariectomy between Day 40 and Day 45 p.c., the plasma progesterone concentration fell by about one-half (Group 2). Pregnancy maintenance after ovariectomy, however, is not associated with a compensatory alteration in the production rate of progesterone (Table 1), since the MCR was not appreciably different from that previously measured in intact animals between Day 30 and parturition.

\section{Masculinizing effects of Norgestrel}

The female offspring of the ovariectomized Norgestrel-treated animals showed gross masculinization of the external genitalia, although dissection showed these guinea-pigs to have ovaries and uteri. Fetal masculinization has been noticed following treatment of the dams with other progestagens (e.g. medroxyprogesterone acetate and Norlutin; Foote, Foote \& Foote, 1968), and the latter authors reported that Wolffian duct tissue was also present. In the present experiments, masculinization of the maternal external genitalia was not seen during pregnancy, but it developed within 5 days after parturition and persisted until the animals were killed, up to 2 weeks later. This is comparable with previous observations in the guinea-pig (Diamond \& Young, 1963; Diamond, Rust \& Westphal, 1969) that pregnancy affords protection against masculinization after androgen administration, probably due to enhanced binding of the steroid by high-affinity serum proteins. Norgestrel is bound by some component $(\mathrm{s})$ of pregnant guinea-pig plasma, of similar isoelectric point to the progesterone-binding components. High affinity progesterone-binding by guineapig plasma disappears soon after parturition.

\section{DISCUSSION}

The vital rôle of progesterone in decidual development, and the initiation of the changes that impose the pattern of steroid metabolism seen in pregnancy upon the maternal organism has been discussed previously (Deanesly, 1963, 1972; Illingworth et al., 1970; Illingworth \& Deanesly, 1972). Arterial progesterone concentrations in ovariectomized Norgestrel-treated guinea-pigs are closely correlated to placental growth and do not increase significantly until after Days 25 to 30 of pregnancy. It is evident therefore that the increase in progesterone production rate between Days 15 and 30 in the intact pregnant guineapig is due largely to increased ovarian progesterone secretion. The embryo appears to have a direct luteotrophic effect upon the CL, increasing their steroid output. The production of progesterone by the intact pregnant guinea-pig appears far in excess of its need, since ovariectomy and a reduction in secretion to $25 \%$ of the original calculated value is still compatible with the maintenance of pregnancy. 
Although placental progesterone production becomes important only late in pregnancy, the similarity between oestrogen levels in intact and ovariectomized guinea-pigs, and the failure of ovariectomy to cause a fall in oestrogen concentrations, suggests that measurement of arterial oestrogens relates closely to an extra-ovarian site of secretion. The most likely sites of production would be the fetus and/or placenta and the maternal adrenals. In those guinea-pigs which did not abort and/or die after adrenalectomy, the concentration of total unconjugated oestrogens and progesterone in arterial plasma samples were similar to those in intact animals. It is thus unlikely that the maternal adrenal secretes either large amounts of oestrogens, progesterone or neutral steroid precursors for placental aromatization.

The feto-placental system appears to be the principal site of oestrogen biosynthesis in the pregnant guinea-pig. The rather low levels of total unconjugated oestrogens in pregnant guinea-pigs, as measured by our radioimmunoassay, may be a reflection of a rapid conjugation of oestrogens in this species (Støa \& Børjesson, 1971), or the presence in the circulation of oestrogens other than oestrone or oestradiol-17 $\beta$. During the continuous infusion of $\left[{ }^{3} \mathrm{H}\right]$ androstenedione into pregnant guinea-pigs, we have obtained evidence of conversion to polar phenolic products, one of which has been tentatively identified as oestriol (Challis \& Illingworth, 1972). This steroid has a low cross-reaction in the radioimmunoassay system employed.

The rôle of oestrogens, however, in promoting delivery in the guinea-pig is less well defined than in the rat (Csapo, 1969) or sheep (Challis, 1971; Bedford, Challis, Harrison \& Heap, 1972), where rising oestrogens constitute a prominent feature of parturition. It remains to be seen whether the decline in the concentration of total unconjugated oestrogens seen in intact and ovariectomized guinea-pigs during late gestation may be concerned with the induction of parturition in this species.

\section{ACKNOWLEDGMENTS}

We are grateful to Mrs N. Ackland for her competent technical assistance, and to Dr R. B. Heap for his advice during the preparation of this manuscript. This work was supported by Fellowships from the Lalor Foundation.

\section{REFERENGES}

Artunkal, T. \& Colonge, R. A. (1949) Action de l'ovariectomie sur la gestation du cobaye. C.r. Séanc. Soc. Biol. 143, 1590.

Bedford, G. A., Ghaldis, J. R. G., Harrison, F. A. \& Heap, R. B. (1972) The rôle of oestrogens and progesterone in the onset of parturition in various species. 7. Reprod. Fert. Suppl. 16, 1.

Brooks, R. V., Glayton, B. E. \& Hammond, J. E. (1960) Some observations on the excretion of 17ketosteroids and 17-ketogenic steroids by guinea-pigs. F. Endocr. 20, 24.

Ghallrs, J. R. G. (1971) Sharp increase in free circulating oestrogens immediately before parturition in sheep. Nature, Lond. 229, 208.

Chatiss, J. R. G., Heap, R. B. \& Illingworth, D. V. (1971) Goncentrations of oestrogen and progesterone in the plasma of non-pregnant, pregnant and lactating guinea-pigs. F. Endocr. 51, 333.

Chaldis, J. R. G. \& Illingworth, D. V. (1972) Oestrogens in the pregnant guinea-pig. F. Reprod. Fert. 31, 504 . 
Clayton, B. E. \& Prunty, F. T. G. (1953) The relation of adrenocortical function to scurvy in guineapigs. The effect of exogenous ACTH and adrenalectomy. F. Endocr. 9, 370.

Courrier, R., KeHL, R. \& Raynaud, R. (1929) Neutralisation de l'hormone folliculaire chez la femelle gestante castrée. C.r. Séanc. Soc. Biol. 100, 1103.

Csapo, A. (1969) The four direct regulatory factors of myometrial function. In: Progesterone; its Regulatory Effect on the Myometrium, Ciba Foundation Study Group No. 34, p. 13. Eds. G. E. W. Wolstenholme and J. Knight. Churchill, London.

DEANESLY, R. (1963) Early embryonic growth and progesterone function in ovariectomized guinea-pigs. J. Reprod. Fert. 6, 143.

Deanesly, R. (1972) Retarded embryonic development and pregnancy termination in ovariectomized guinea-pigs; progesterone deficiency and decidual collapse. F. Reprod. Fert. 28, 241.

Diamond, M., Rust, N. \& Westrhal, U. (1969) High-affinity binding of progesterone, testosterone and cortisol in normal and androgen-treated guinea-pigs during various reproductive stages. Relationship to masculinization. Endocrinology, 87, 1143.

Diamond, M. \& Young, W. C. (1963) Differential responsiveness of pregnant and non-pregnant guinea-pigs to the masculinizing action of testosterone propionate. Endocrinology, 72, 429.

Foote, W. D., Foote, W. C. \& Foote, L. H. (1968) Influence of certain natural and synthetic steroids on genital development in guinea-pigs. Fert. Steril. 19, 606.

Heap, R. B. \& Deanesly, R. (1966) Progesterone in systemic blood and placentae of intact and ovariectomized pregnant guinea-pigs. F. Endocr. 34, 417.

HERRIGK, E. H. (1928) The duration of pregnancy in guinea-pigs after removal and also after transplantation of the ovaries. Anat. Rec. 39, 193.

Illingworth, D. V. \& DeANesly, R. (1972) Maintenance of pregnancy by synthetic progestagens in guinea-pigs ovariectomized before implantation; progesterone-binding protein and placental progesterone secretion. 7. Endocr. 54, 435.

Illingworth, D. V., Heap, R. B. \& Perry, J. S. (1970) Changes in the metabolic clearance rate of progesterone in the guinea-pig. F. Endocr. 48, 409.

StøA, K. F. \& BørJesson, B. W. (1971) Metabolism of oestradiol-17 $\beta$ in the guinea-pig. Biochim. biophys. Acta, 239, 337.

Thorburn, G. D., Bassetr, J. M. \& SMrth, I. D. (1969) Progesterone concentrations in peripheral plasma of sheep during the oestrous cycle. 7 . Endocr. $45,459$. 